\title{
Growth and Yield of Hybrid Maize (Zea mays L.) in Relation to Planting Density and Nitrogen Levels during Winter Season in Nepal
}

\author{
D.R. Dawadi ${ }^{*}$ and S.K. Sah ${ }^{1}$ \\ Chamber of Commerce and Industry \\ Chitwan \\ Nepal
}

ABSTRACT. A field experiment was conducted at the National Maize Research Program (NMRP) Farm, Rampur, Chitwan during winter season, 2008/09 to study the effects of three plant densities (55,555, 66,666 and 83,333 plants/ha) and three nitrogen levels (120, 160 and $200 \mathrm{~kg} / \mathrm{ha}$ ) on yield and yield attribute of hybrid maize (Zea mays L.) varieties Gaurav, (a Nepali hybrid) and Rajkumar (an Indian hybrid). The results showed that plant height increases with increasing plant density and nitrogen level. Similarly, phenology was not influenced by the densities whereas variety and nitrogen levels had a significant effect on tasseling, silking and physiological maturity. Plant density of 66,666 plants/ha produced the higher grain yield $(11.19 \mathrm{t} / \mathrm{ha})$ compared to that of $55,555 \mathrm{plants} / \mathrm{ha}(9.52 \mathrm{t} / \mathrm{ha})$. However, grain yield at 66,666 plants/ha did not show a significant difference with that of 83,333 plants/ha (10.54 t/ha). Increasing plant density from 55,555 plants/ha to 83,333 plants/ha had increased the stover yield, whereas, the Harvest Index (HI) and grain stover ratio were not significantly influenced by plant densities. Similarly, $200 \mathrm{~kg} / \mathrm{ha} N$ application produced a higher grain yield (10.9 t/ha) than $120 \mathrm{~kg} / \mathrm{ha} N$ application $(9.76 \mathrm{t} / \mathrm{ha})$, but was in par with $160 \mathrm{~kg} / \mathrm{ha} N$ application $(10.59 \mathrm{t} / \mathrm{ha})$. The yield of the two hybrid maize varieties had no significant difference. Plant density with 66,666 plants/ha and $160 \mathrm{~kg} / \mathrm{ha} N$ application was the most appropriate for inner terai environments of Nepal during winter season.

Keywords: Hybrid maize, density, nitrogen, growth and yield

\section{INTRODUCTION}

Maize (Zea mays L.) is the world's widely grown highland cereal and primary staple food crop in many developing countries. It is the second most important staple food crop both in terms of area and production after rice in Nepal (ABPSD, 2008). Total area under cultivation of maize in Nepal is $8,70,166$ ha, which is about $28.15 \%$ of the total cultivated agricultural land while average yield is $2.15 \mathrm{tha}^{-1}$. It is about $23.28 \%$ of the total cereal production and $6.87 \%$ to Agricultural Gross Domestic Product in Nepal (MOAC, 2007/08). The crop is grown under rain-fed conditions during the summer (April- August) as a sole crop or relayed with millet later in the season. In the winter and spring it is grown in the terai, inner terai and low-lying river basin areas, with partial irrigation (Paudyal et al, 2001). The rapidly increasing demand of maize is driven by increased in demand for direct human consumption in the hills as a staple food crop (Ghimire et al., 2007) and for livestock feeds in terai and inner terai areas (Pandey et al., 2007). Terai and inner terai have high potential for hybrid maize

\footnotetext{
1 Department of Agronomy, Institute of Agriculture and Animal Sciences (IAAS), Rampur Campus, Chitwan, Nepal

* Author for correspondence: alovevera79@yahoo.com
} 
cultivation particularly in spring and winter seasons. Less plant population and poor nutrient management practices are the major yield reducing factors in maize. Average plant density in farmer's field lays around 40,000 (Gurung \& Rijal, 1993). Increasing plant density would require more fertilizer especially nitrogen and water. The nitrogen recommendation for maize in Nepal is based on open pollinated varieties. Most of the farmers use high amount of nitrogen fertilizer haphazardly since there is little information available on nitrogen requirement for hybrid maize production in Nepal. Therefore, a field study was undertaken to determine the optimum density and nitrogen level for hybrid maize varieties during winter season under inner Terai environments of Nepal.

\section{MATERIALS AND METHODS}

A field experiment was conducted at National Maize Research Program (NMRP) Farm, Rampur, Chitwan from September, 2008 to July 2009. The site is located in central Nepal at $27^{\circ} 37^{\prime} \mathrm{N}$ latitude and $84^{\circ} 25^{\prime} \mathrm{E}$ longitude with an elevation of 256 meters above mean sea level and has a sub tropical climate (Thapa \& Dangol, 1988). The soil type was a sandy loam with $\mathrm{pH}$ of 6.5 , organic matter $2.69 \%$, total nitrogen $0.12 \%$, available phosphorus $178.60 \mathrm{~kg} \mathrm{ha}^{-1}$ and potassium $120.60 \mathrm{~kg} \mathrm{ha}^{-1}$. The experiment consisted 18 treatments (Table1) with a combination of three population densities $(55,555 ; 66,666$ and 83,333 plants/ha) in main plots, two hybrid varieties (Nepali hybrid Gaurav and Indian hybrid Bioseed Rajkumar) in sub plot and three levels of nitrogen (120, 160 and $\left.200 \mathrm{~kg} \mathrm{ha}^{-1}\right)$ in subsub plots with three replications in a split-split plot design.

Crop was planted in a plot size of $14.4 \mathrm{~m}^{2}(3 \mathrm{~m} \times 4.8 \mathrm{~m})$ at a spacing of $60 \mathrm{~cm}$ between rows and $20 \mathrm{~cm}, 25 \mathrm{~cm}$ and $30 \mathrm{~cm}$ with in rows, respectively. The crop was planted in September in 2008/09. Farm yard manure (FYM) at the rate of $10 \mathrm{t} / \mathrm{ha}$ was applied to all experimental plots. The maize crop was fertilized with 120/160/200:60:40 kg N: $\mathrm{P}_{2} \mathrm{O}^{5}: \mathrm{K}_{2} \mathrm{O}$ per ha. Urea, Diammonium phosphate (DAP) and Murate of Potash (MOP) were the fertilizers used. Of this $50 \%$ of nitrogen, full $100 \%$ of phosphorous and potassium fertilizers were applied as basal and remaining $50 \%$ of nitrogen was split first at knee high stage (top dressing) and second at tasseling stage (side dressing). Thinning was done at $25^{\text {th }}$ day after sowing (DAS) to maintain a single plant per hill. Furadon ( $3 \%$ C.G) 2-3 granules per plant of maize was applied against the stem borer to the uppermost whorls of leaves at the grand growth stage (40 DAS). Two manual weedings were done throughout the maize growing period, $1^{\text {st }}$ at knee-high (25 DAS) and $2^{\text {nd }}$ at tasseling stage (55 DAS). Irrigations was done two times during the growing period of maize hybrids, $1^{\text {st }}$ at grand growth stage (40 DAS) and second at tasseling stage (60 DAS). MSTAT-C package was used for data analysis. Mean separation was done at $5 \%$ level of significance by using Duncan Multiple Range Test (DMRT). 
Table 1. Treatment combinations of plant densities, varieties and nitrogen levels

\begin{tabular}{lc}
\hline Treatment & Plant density-variety-nitrogen level \\
\hline T1 & $\mathrm{D}_{1} \mathrm{~V}_{1} \mathrm{~N}_{1}$ \\
T2 & $\mathrm{D}_{1} \mathrm{~V}_{1} \mathrm{~N}_{2}$ \\
T3 & $\mathrm{D}_{1} \mathrm{~V}_{1} \mathrm{~N}_{3}$ \\
T4 & $\mathrm{D}_{1} \mathrm{~V}_{2} \mathrm{~N}_{1}$ \\
T5 & $\mathrm{D}_{1} \mathrm{~V}_{2} \mathrm{~N}_{2}$ \\
T6 & $\mathrm{D}_{1} \mathrm{~V}_{2} \mathrm{~N}_{3}$ \\
T7 & $\mathrm{D}_{2} \mathrm{~V}_{1} \mathrm{~N}_{1}$ \\
T8 & $\mathrm{D}_{2} \mathrm{~V}_{1} \mathrm{~N}_{2}$ \\
T9 & $\mathrm{D}_{2} \mathrm{~V}_{1} \mathrm{~N}_{3}$ \\
T10 & $\mathrm{D}_{2} \mathrm{~V}_{2} \mathrm{~N}_{1}$ \\
T11 & $\mathrm{D}_{2} \mathrm{~V}_{2} \mathrm{~N}_{2}$ \\
T12 & $\mathrm{D}_{2} \mathrm{~V}_{2} \mathrm{~N}_{3}$ \\
T13 & $\mathrm{D}_{3} \mathrm{~V}_{1} \mathrm{~N}_{1}$ \\
T14 & $\mathrm{D}_{3} \mathrm{~V}_{1} \mathrm{~N}_{2}$ \\
T15 & $\mathrm{D}_{3} \mathrm{~V}_{2} \mathrm{~N}_{3}$ \\
T16 & $\mathrm{D}_{3} \mathrm{~V}_{2} \mathrm{~N}_{1}$ \\
T17 & $\mathrm{D}_{3} \mathrm{~V}_{2} \mathrm{~N}_{2}$ \\
T18 & $\mathrm{D}_{3} \mathrm{~V}_{3} \mathrm{~N}_{3}$ \\
\hline
\end{tabular}

Plant density: $\mathrm{D}_{1^{-}}-55,555$ plants/ha $\mathrm{D}_{2^{-}}-66,666$ plants/ha $\mathrm{D}_{3}-83,333$ plants/ha

Variety: $\mathrm{V}_{1}$ - Gaurav $\mathrm{V}_{2}$ - Rajkumar

Nitrogen levels: $\mathrm{N}_{1}-120 \mathrm{~kg} / \mathrm{ha} \mathrm{N} \mathrm{N}_{2}-160 \mathrm{~kg} / \mathrm{ha} \mathrm{N}_{3}-200 \mathrm{~kg} / \mathrm{ha}$

\section{RESULTS AND DISCUSSION}

\section{Effect on plant height}

Plant height was significantly influenced by the densities, varieties and nitrogen levels (Table 2). Plant height increased with increase in plant density and the taller plants were observed in 83,333 plants/ha density. This was mainly due to increased competition for light. In agreement with the results of the present study increase in plant density increased the plant height of maize hybrid Gaurav (Adhikari et al., 2004). Hybrid maize Rajkumar was significantly taller than Gaurav. Taller plants of Rajkumar might be due to its genetically governed characteristics. Increasing nitrogen level from $120 \mathrm{~kg} / \mathrm{ha}$ to $200 \mathrm{~kg} / \mathrm{ha}$ also increased the plant height of hybrid maize varieties (Table 2). Higher $\mathrm{N}$ applications increase the cell division, cell elongation, nucleus formation as well as green foliage. It also encourages the shoot growth. Therefore, higher doses of nitrogen increased the chlorophyll content which increased the rate of photosynthesis and extension of stem resulting increased plant height (Thakur et al., 1997; Diallo et al., 1996).

\section{Effect on phenology}

Days to $90 \%$ tasseling, silking, Anthesis Silking Interval (ASI) and physiological maturity were not significantly influenced by plant density. However, there as a lower number of days to silking, tasseling and physiological maturity and increasing ASI with increases in plant density observed from 55,555 plants ha ${ }^{-1}$ to 83,333 plants/ha (Table 2 ). Significantly longer seed fill duration was observed in 55,555 plants/ha (94.33 days) than the higher with 83,333 
plants/ha (90.94 days). The seed fill duration in 66,666 and 83,333 plants/ha was similar. Poneleit and Egli (1979) have found 2.5 days less effective filling period (EFP) at the high plant density. Significantly earlier tasseling and silking and shorter physiological maturity was observed in the variety Rajkumar. Early tasseling, silking and short physiological maturity of Rajkumar might be due to its genetic characteristics. Azam et al., (2007) reported different tasseling days for different maize varieties.

Increasing nitrogen level from $120 \mathrm{~kg} / \mathrm{ha}$ to $200 \mathrm{~kg} / \mathrm{ha}$ decreased the tasseling, silking and ASI but increased the physiological maturity and seed fill duration (SFD) (Table 2). Rai (1961) reported that application of nitrogen as well as increase in its rate induced earliness of tasseling and silking stages. The shorter ASI with higher nitrogen was because of inducing early and rapid growth. Prasad and Singh (1990) also observed a decrease in ASI with increasing levels of N application. Shrestha (2007) reported increased physiological maturity and SFD with increasing levels of nitrogen in open pollinated varieties of maize. Delayed maturity at higher nitrogen was because the plant was staying green. Higher nitrogenous fertilizer delays the senescence of leaves and increased succulence of plants.

Interaction among densities, varieties and nitrogen level were non-significant for final plant height, tasseling, silking, ASI, physiological maturity and SFD.

Table 2. Effect of treatments on plant height and phenology of hybrid Maize

\begin{tabular}{|c|c|c|c|c|c|c|}
\hline Treatment & $\begin{array}{c}\text { Final plant } \\
\text { height, } \\
\text { (cm) }\end{array}$ & $\begin{array}{c}90 \% \\
\text { Tasseling } \\
\text { (days) } \\
\end{array}$ & $\begin{array}{c}\begin{array}{c}90 \% \\
\text { Silking } \\
\text { (days) }\end{array} \\
\end{array}$ & $\begin{array}{c}\text { ASI } \\
\text { (days) }\end{array}$ & $\begin{array}{c}\text { Physiological } \\
\text { Maturity } \\
\text { (DAS) }\end{array}$ & $\begin{array}{c}\text { SFD } \\
\text { (days) }\end{array}$ \\
\hline \multicolumn{7}{|l|}{ Density } \\
\hline 55,555 plant/ha & $208.9^{\mathrm{b}}$ & 58.27 & 62.55 & 4.16 & 152.61 & $94.33^{\mathrm{a}}$ \\
\hline 66,666 plant/ha & $217.5^{\mathrm{ab}}$ & 58.28 & 63.22 & 4.94 & 148.22 & $89.94^{\mathrm{b}}$ \\
\hline 83,333 plant $/$ ha & $225.8^{\mathrm{a}}$ & 59.16 & 64.55 & 5.38 & 150.11 & $90.94^{\mathrm{b}}$ \\
\hline LSD & $10.30 *$ & Ns & Ns & Ns & Ns & $3.27 *$ \\
\hline SE & 2.62 & 0.61 & 0.59 & 0.16 & 1.24 & 0.83 \\
\hline \multicolumn{7}{|l|}{ Variety } \\
\hline Gaurav & $210.2^{\mathrm{b}}$ & $60.22^{\mathrm{a}}$ & $64.89^{\mathrm{a}}$ & 4.66 & $152.2^{\mathrm{a}}$ & 92.00 \\
\hline Rajkumar & $224.6^{\mathrm{a}}$ & $56.93^{\mathrm{b}}$ & $62.00^{\mathrm{b}}$ & 5.00 & $148.4^{\mathrm{b}}$ & 91.48 \\
\hline LSD & $2.75^{*}$ & $1.37 * *$ & $0.79 * *$ & Ns & $2.60 * *$ & Ns \\
\hline $\mathrm{SE}$ & 0.79 & 0.39 & 0.22 & 0.97 & 0.75 & 1.00 \\
\hline $\mathrm{CV}_{\mathrm{b}}$ & 3.34 & 3.51 & 1.87 & 25.35 & 2.59 & 5.71 \\
\hline \multicolumn{7}{|l|}{ Nitrogen } \\
\hline $\mathrm{N} @ 120 \mathrm{~kg} / \mathrm{ha}$ & $208.22^{\mathrm{c}}$ & $59.06^{\mathrm{a}}$ & $64.33^{\mathrm{a}}$ & $5.27^{\mathrm{a}}$ & $149.4^{\mathrm{c}}$ & $90.33^{\mathrm{c}}$ \\
\hline N@160kg/ha & $218.77^{\mathrm{b}}$ & $58.72^{\mathrm{a}}$ & $63.56^{\mathrm{b}}$ & $4.83^{\mathrm{b}}$ & $150.3^{\mathrm{b}}$ & $91.56^{\mathrm{b}}$ \\
\hline N@200kg/ha & $225.16^{\mathrm{a}}$ & $57.94^{\mathrm{b}}$ & $62.44^{\mathrm{c}}$ & $4.38^{\mathrm{c}}$ & $151.3^{\mathrm{a}}$ & $93.33^{\mathrm{a}}$ \\
\hline LSD & $3.27 *$ & $0.47 * *$ & $0.63 * *$ & $0.26^{* *}$ & $0.64 * *$ & $0.81^{* *}$ \\
\hline $\mathrm{SE}$ & 1.12 & 0.16 & 0.21 & 0.09 & 0.21 & 0.28 \\
\hline $\mathrm{CV}_{\mathrm{c}}$ & 2.19 & 1.17 & 1.45 & 8.21 & 0.62 & 1.30 \\
\hline Grand mean & 217.38 & 58.57 & 63.44 & 4.83 & 150.31 & 91.74 \\
\hline
\end{tabular}

Means followed by the common letter within each column are not significantly different at $5 \%$ level of significance by DMRT, * Significant at $\mathrm{P}=0.05$, ** Significant at $\mathrm{P}=0.01$ level of significance 


\section{Effect on yield attributes}

The number of plants at harvest, number of harvested ears ('000), barrenness and stalk lodging percentage increased with increasing plant density whereas the number of kernel rows/ear, number of kernels/ear and thousand grain weight (TGW) decreased (Table 3). The lowest number of kernels/ear at high plant density may be due to high competition for the resources such as light, moisture and fertilizer. Hashemi et al. (2005) reported a linear decline in number of kernel rows/ear with increasing plant density. The high barrenness (\%) at high densities was due to the absence of the usual sink for the assimilate supply and limiting optimum conversion of light energy to grain in maize grown at high plant densities which inhibited the plants to produce viable ears. Ritchie and Alagarswamy (2003) reported that barrenness occurred more frequently when plant densities exceed 10plants $/ \mathrm{m}^{2}$. Similarly, plants become taller and weaker at higher densities which lead to higher lodging. Gardner et al. (1985) also reported the increased lodging with increasing plant density.

The number of kernel rows/ear, shelling $\%$, Barrenness $\%$ and stalk lodging $\%$ were significantly influenced by the varieties (Table 3). The higher number of kernel rows/ear in the variety Gaurav might be due to its genetic characters. There was a trend of increasing number of kernel rows/ear, number of kernel/ear and TGW with increasing doses of $\mathrm{N}$ application. However, number of plants at harvest, number of harvested ears, shelling \%, barrenness \% and stalk lodging \% were not significantly influenced by nitrogen levels (Table 3 ). The higher degree of barrenness under lower nitrogen application might be attributed to poor development of sinks and reduced translocation of photosynthates. Under nitrogen stress environments there may be asynchronous flowering, abortion of seed, and ultimately the reduction in the number of seeds. Gungula et al. (2007) reported that there will be more synchrony in flowering with higher nitrogen, thus reducing the rate of barrenness during grain filling period. In agreement with the results of the present study, increased in TGW has been reported with increase in nitrogen levels (Akbar et al., 2002; Gokmen et al., 2001; Niazuddin et al., 2002).

\section{Effect on yield, stover yield, harvest Index and grain: stover ratio}

Grain yield, stover yield and grain: stover ratios were significantly influenced by plant density (Table 4). The increasing plant density enhanced grain as well as stover yields of hybrid maize but grain: stover ratio was decreased by increasing plant density. The grain yield at plant density 66,666 plants/ha was the highest (11.19 t/ha) and it was significantly higher than the grain yield $(9.52 \mathrm{t} / \mathrm{ha})$ at 55,555 plants $\mathrm{ha}^{-1}$ and not significantly different from the yield (10.54 t/ha) at 83,333 plants/ha. The grain yield obtained at 83,333 plants/ha ${ }^{1}$ was also statistically similar to grain yield at 55,555 plants/ha. The positive relationship between grown yield and plant density was due to the high number of ears harvested and high number of plants per unit area. The increase of stover yield with the increase of plant densities may be due to increasing numbers of plants and dry matter yield. Vega et al. (2000) reported that maize grain yield is affected to a greater extent by variations in plant density than in other members of the grass family due to its tillering capacity. Tollenaar et al. (1997) also reported that maize grain yield declines when plant density is increased beyond an optimum, primarily because of the decline in harvest index (HI) and increased stem lodging. Such cases represent intense interplant competition for incident photosynthetic flux density, soil nutrients and water. Under higher plant densities, the rate of yield reduction was in response to decreasing light, moisture, nutrient and other environmental resources available to each plant. Scarsbrook and Doss (1973) reported that stover yields of hybrid maize usually increased with each increment of plant population up to 80,000 plants/ha. 
Table 3. Effect of treatments on yield attributes of hybrid maize

\begin{tabular}{|c|c|c|c|c|c|c|c|c|}
\hline Treatment & $\begin{array}{c}\text { No of } \\
\text { plants } \\
\text { at } \\
\text { harvest } \\
\text { '000/ha } \\
\end{array}$ & $\begin{array}{c}\text { Number } \\
\text { of } \\
\text { harvested } \\
\text { ear (' } 000 \\
\text { /ha) } \\
\end{array}$ & $\begin{array}{c}\text { Number } \\
\text { of } \\
\text { kernel } \\
\text { rows /ear }\end{array}$ & $\begin{array}{c}\text { Number } \\
\text { of } \\
\text { kernels } \\
\text { /ear }\end{array}$ & $\begin{array}{c}\text { TGW } \\
\text { (g) }\end{array}$ & $\begin{array}{c}\text { Shelling } \\
\%\end{array}$ & $\begin{array}{c}\text { Barrenness } \\
\%\end{array}$ & $\begin{array}{c}\text { Stalk } \\
\text { lodging } \\
\%\end{array}$ \\
\hline \multicolumn{9}{|l|}{ Density } \\
\hline $\begin{array}{l}55,555 \\
\text { plants/ha }\end{array}$ & $55.34^{\mathrm{c}}$ & $53.70^{\mathrm{c}}$ & $15.16^{\mathrm{a}}$ & $530.1^{\mathrm{a}}$ & $366.3^{\mathrm{a}}$ & 86.23 & $0.93^{c}$ & $1.49^{\mathrm{b}}$ \\
\hline $\begin{array}{l}66,666 \\
\text { plants/ha }\end{array}$ & $64.60^{\mathrm{b}}$ & $63.07^{\mathrm{b}}$ & $14.88^{\mathrm{b}}$ & $500.2^{\mathrm{ab}}$ & $352.5^{\mathrm{b}}$ & 86.00 & $3.05^{\mathrm{b}}$ & $3.49^{\mathrm{ab}}$ \\
\hline $\begin{array}{l}83,333 \\
\text { plants/ha }\end{array}$ & $79.21^{\mathrm{a}}$ & $75.31^{\mathrm{a}}$ & $14.52^{\mathrm{c}}$ & $481.0^{\mathrm{b}}$ & $349.9^{\mathrm{b}}$ & 85.93 & $5.64^{\mathrm{a}}$ & $4.14^{\mathrm{a}}$ \\
\hline LSD & $7.90 * *$ & $3.96 * *$ & $0.23 * *$ & $30.26^{*}$ & $11.23^{*}$ & Ns & $1.91 * *$ & $2.01 *$ \\
\hline SE & 2.01 & 1.01 & 0.06 & 7.70 & 2.86 & 0.27 & 0.48 & 0.51 \\
\hline $\mathrm{CVa}$ & 1.28 & 6.69 & 1.71 & 6.49 & 3.40 & 1.36 & 69.58 & 71.49 \\
\hline \multicolumn{9}{|l|}{ Variety } \\
\hline Gaurav & 66.04 & 63.78 & $15.31^{\mathrm{a}}$ & 497.26 & 353.58 & $84.02^{\mathrm{b}}$ & $4.03^{\mathrm{a}}$ & $2.495^{\mathrm{b}}$ \\
\hline Rajkumar & 66.74 & 64.26 & $14.39^{\mathrm{b}}$ & 510.28 & 358.85 & $88.10^{\mathrm{a}}$ & $2.38^{\mathrm{b}}$ & $3.595^{\mathrm{a}}$ \\
\hline LSD & Ns & Ns & $0.31 * *$ & Ns & Ns & $0.49 * *$ & $1.56^{* * *}$ & $0.71^{* *}$ \\
\hline SE & 1.81 & 0.72 & 0.09 & 5.57 & 2.11 & 0.14 & 0.45 & 0.20 \\
\hline $\mathrm{CVb}$ & 1.42 & 5.90 & 3.15 & 5.74 & 3.09 & 0.86 & 73.32 & 35.05 \\
\hline \multicolumn{9}{|l|}{ Nitrogen } \\
\hline $120 \mathrm{~kg} / \mathrm{ha}$ & 66.04 & 64.50 & $14.46^{\mathrm{c}}$ & $478.6^{\mathrm{c}}$ & $347.9^{\mathrm{b}}$ & 85.83 & 3.46 & 2.54 \\
\hline $160 \mathrm{~kg} / \mathrm{ha}$ & 66.35 & 63.68 & $14.91^{\mathrm{b}}$ & $501.8^{\mathrm{b}}$ & $357.3^{\mathrm{a}}$ & 86.11 & 3.45 & 2.65 \\
\hline $200 \mathrm{~kg} / \mathrm{ha}$ & 66.76 & 63.88 & $15.19^{\mathrm{a}}$ & $530.9^{\mathrm{a}}$ & $363.5^{\mathrm{a}}$ & 86.22 & 2.71 & 3.93 \\
\hline LSD & Ns & Ns & $0.20 * *$ & $12.37 * *$ & $6.44 * *$ & Ns & Ns & NS \\
\hline SE & 0.26 & 0.70 & 0.07 & 4.23 & 2.20 & 0.15 & 0.41 & 0.43 \\
\hline $\mathrm{CVc}$ & 1.71 & 4.68 & 2.00 & 3.56 & 2.63 & 0.74 & 54.74 & 60.10 \\
\hline Grand mean & 66.39 & 64.02 & 14.85 & 503.77 & 356.22 & 86.06 & 3.21 & 3.04 \\
\hline
\end{tabular}

Means followed by the common letter within each column are not significantly different at $5 \%$ level of significance by DMRT, *Significant at $\mathrm{P}=0.05, * *$ Significant at $\mathrm{P}=0.01$ level of significance.

There were marginal differences in the grain yield between varieties whereas stover yield, grain stover ratio and $\mathrm{HI}$ were found to be significantly influenced by the plant density (Table 4). Significantly higher stover yields were observed in maize variety Gaurav (13.88 $\mathrm{t} / \mathrm{ha}$ ) than in Indian hybrid Rajkumar (11.26 t/ha). The higher stover yield of Gaurav was because of a low HI when compared to Indian hybrid Rajkumar. Significantly higher HI and grain stover ratio were observed in the hybrid variety Rajkumar $(0.46 \& 0.85$ respectively) than in Indian hybrid Gaurav ( $0.42 \& 0.75$ respectively). Grain yield, stover yield, HI and grain stover ratio were significantly influenced by the nitrogen levels (Table 4). Increasing nitrogen levels from $120 \mathrm{~kg} / \mathrm{ha}$ to $200 \mathrm{~kg} / \mathrm{ha}$ enhanced the grain yield and stover yield of hybrid maize whereas, increasing nitrogen levels decreased the HI and grain stover ratio. The grain yield was highest $(10.9 \mathrm{t} / \mathrm{ha}$ ) with $200 \mathrm{~kg} / \mathrm{ha} \mathrm{N}$ level. It was significantly higher than the yield received $120 \mathrm{~kg} / \mathrm{ha} \mathrm{N}$ level $(9.76 \mathrm{t} / \mathrm{ha})$ but similar to that with $160 \mathrm{~kg} / \mathrm{ha} \mathrm{N}$ level (10.59 t/ha). 
Table 4. Effect of treatments on grain yield, stover yield, harvest index and grain: stover ratio of hybrid maize

\begin{tabular}{lllll}
\hline Factors & $\begin{array}{c}\text { Grain yield } \\
(\mathbf{t} / \mathbf{h a})\end{array}$ & $\begin{array}{c}\text { Stover yield } \\
(\mathbf{t} / \mathbf{h a})\end{array}$ & Harvest index & Grain: Stover ratio \\
\hline Density & & & & \\
$55,555 \mathrm{plant} / \mathrm{ha}$ & $9.52^{\mathrm{b}}$ & $12.29^{\mathrm{c}}$ & 0.43 & $0.78^{\mathrm{b}}$ \\
66,666 plant/ha & $11.19^{\mathrm{a}}$ & $13.17^{\mathrm{b}}$ & 0.46 & $0.86^{\mathrm{a}}$ \\
83,333 plant/ha & $10.54^{\mathrm{ab}}$ & $13.91^{\mathrm{a}}$ & 0.43 & $0.76^{\mathrm{b}}$ \\
$\mathrm{LSD}$ & $1.18^{*}$ & $0.72^{* *}$ & $\mathrm{Ns}$ & $0.07^{* *}$ \\
$\mathrm{SE}$ & 0.30 & 0.18 & 0.007 & 0.01 \\
$\mathrm{CV}{ }_{\mathrm{a}} \%$ & 12.25 & 6.00 & 7.18 & 9.61 \\
Variety & & & & \\
Gaurav & 10.35 & $13.88^{\mathrm{a}}$ & $0.42^{\mathrm{b}}$ & $0.75^{\mathrm{b}}$ \\
Rajkumar & 10.4 & $12.36^{\mathrm{b}}$ & $0.46^{\mathrm{a}}$ & $0.85^{\mathrm{a}}$ \\
$\mathrm{LSD}$ & $\mathrm{Ns}$ & $0.91^{* *}$ & $0.02^{* *}$ & $0.07^{* *}$ \\
$\mathrm{SE}$ & 0.22 & 0.26 & 0.006 & 0.02 \\
$\mathrm{CV} \mathrm{b}_{\mathrm{b}} \%$ & 11.26 & 10.50 & 7.18 & 14.68 \\
Nitrogen & & & & \\
$120 \mathrm{~kg} / \mathrm{ha}$ & $9.76^{\mathrm{b}}$ & $11.45^{\mathrm{c}}$ & $0.46^{\mathrm{a}}$ & $0.85^{\mathrm{a}}$ \\
$160 \mathrm{~kg} / \mathrm{ha}$ & $10.59^{\mathrm{a}}$ & $13.06^{\mathrm{b}}$ & $0.44^{\mathrm{ab}}$ & $0.82^{\mathrm{a}}$ \\
$200 \mathrm{~kg} / \mathrm{ha}$ & $10.90^{\mathrm{a}}$ & $14.85^{\mathrm{a}}$ & $0.42^{\mathrm{b}}$ & $0.73^{\mathrm{b}}$ \\
$\mathrm{LSD}$ & $0.52^{* *}$ & $0.49^{* *}$ & $0.01^{*}$ & $0.04^{*}$ \\
$\mathrm{SE}$ & 0.18 & 0.17 & 0.00 & 0.01 \\
$\mathrm{CV} V_{\mathrm{c}} \%$ & 7.38 & 5.50 & 3.95 & 9.10 \\
Grand mean & 10.42 & 13.12 & 0.44 & 0.80 \\
\hline
\end{tabular}

Means followed by the common letter within each column are not significantly different at $5 \%$ level of significance by DMRT. * Significant at $\mathrm{P}=0.05$, ** Significant at $\mathrm{P}=0.01$ level of significance.

The increasing nitrogen levels caused the increase of the number of kernel rows per ear, number of kernel per ear and TWG which, in turn, increased the grain yield. Similarly, stover yield was highest (14.85 t/ha) in $200 \mathrm{~kg} / \mathrm{ha} \mathrm{N}$ applied plot and it was significantly higher than those of the plots received $160 \mathrm{~kg} / \mathrm{ha} \mathrm{N}(13.06 \mathrm{t} / \mathrm{ha})$ and $120 \mathrm{~kg} / \mathrm{ha} \mathrm{N}(11.45 \mathrm{t} / \mathrm{ha})$. Singh et al. (2000) indicated that grain and stover yield increased with the increase in nitrogen level from $0-200 \mathrm{~kg} / \mathrm{ha}$. Ullah et al. (2007) also reported the increased grain and stover yield with increasing nitrogen levels.

Interaction among densities, varieties and nitrogen levels were not significant for number of harvested ear, number of kernel rows/ear, number of kernels/ear, TGW and grain yield.

\section{CONCLUSIONS}

The plant density of 66,666 plants/ha produced the highest grain yield in hybrid maize. The recommended density of 53,333 plants/ha is insufficient for hybrid maize cultivation in Chitwan. Therefore, closer spacing with a plant density around 65-70 thousands/ha is suitable for the higher yield of hybrid maize during winter seasons in Chitwan. Although, higher rates of nitrogen up to $200 \mathrm{~kg} / \mathrm{ha}$ increased the yield of hybrid maize, the yields were not significantly different at 160 and $200 \mathrm{~kg} / \mathrm{ha} \mathrm{N}$ levels. Therefore, $160 \mathrm{~kg} / \mathrm{ha} \mathrm{N}$ was the appropriate dose for hybrid maize cultivation in inner terai environments of Nepal. 
Similarly, Yield of Nepali hybrid Gaurav, was similar to that of the Indian hybrid Bioseed Rajkumar. Thus, the private sectors should come forward to produce hybrid seed of Nepali Maize variety (Gaurav) in order to promote its production.

\section{ACKNOWLEDGEMENT}

We acknowledge National Agricultural Research and Development Fund (NARDF), Singh Durbar Plaza, Kathmandu, Nepal for providing a research grant and Institute of Agriculture and Animal Science (IAAS), Rampur, Chitwan, Nepal as well as National Maize Research Program (NMRP), Rampur, Chitwan for providing research facilities.

\section{REFERENCES}

ABPSD. (2008). Statistical information of Nepalase Agriculture 2007/2008. Agribusiness Promotion and Statistics Division, Kathmandu, Nepal. pp.127.

Adhikari, B.H., D. P. Sherchan. and D. D. Neupane. (2004). Effect of nitrogen levels on the production of maize (Zea mays) planted at varying densities in the Chitwan valley. In: N. P. Rajbhandari, J.K. Ransom, K. Adhikari. and A. F. E. Palmar (eds.). Proceedings of Maize Symposium, December 3-5, 2001, Nepal, NARC/CIMMYT. pp. 216-219.

Akbar, H., M. Maftihullah, T. Jan, A. Jan and I. Hsanullah. (2002). Yield potential of sweet corn as influenced by different levels of nitrogen and plant population. Asian J. Pl. Sci. 1(6),631-633.

Azam, S., Ali, M. Amin., S. Bibi. and Arif. M. (2007). Effect of plant population on maize hybrids. J. Agron. Bio.Sci. 2,13-16.

Diallo, A.O., Adam, A., Akanvou. R.K. and Sallah, P. Y. K. (1996). Response of maize lines evaluated under stress and non-stress environments. In: G. O. Edmeades, M. Banziger, H. R. Mickelson and C. B. Pena-Valdivia (eds.) Developing Drought and Low N Tolerance Maize. Proceedings of a Symposium, March 25-29, 1996. CIMMYT, EI Batan, Mexico. pp. 280286.

Gardner, F.P., Pearce, R.B. and Mitchell, R.L. (1985). Physiology of crop plants. Iowa State University Press. Ames, USA.

Ghimire, K.H., Koirala, K.B., BK, S.B., Prasai, H.K. and Poudel, R.P. (2007). Full season maize varietal research in western hills of Nepal (2004-2006). pp. 147-156.In: Gurung, D.B., Paudel, D.C., KC, G., Upadhaya, S.R. and Pokhrel, B.B. (eds.) Proceedings of the $25^{\text {th }}$ National Summer Crops Research Workshop on Maize Research and Production in Nepal held in June 21-23, 2007 at NARC, Khumaltar, Lalitpur, Nepal.

Gokmen, S., Sencar, O. and Sakin, M.A. (2001). Response of popcorn ( Zea mays everta) to nitrogen rates and planting densities. Turk. J. Agric. 25,15-23.

Gungula, D.T., Togun, A.O. and Kling, J.G. (2007). The effect of nitrogen rates on phenology and yield components of early maturing maize cultivars. Glob. J. Pur. App. Sci. 13(3), 319-324. 
Gurung, B.D. and Rijal, D.K. (1993). Plant population study of maize. PAC Working Paper No. $45,1-9$.

Hashemi, A.M., Herbert, S.J. and Putnam, D.H. (2005). Yield response of corn to crowding stress. Agron. J. 97,839-846.

MOAC. 2007/08. Statistical information on Nepalese agriculture, 2006/2007 (2063/2064). Agribusiness Promotion and Statistics Division, Singhadarbar, Kathmandu, Nepal.127p.

Niazuddin, M., Talukder, M.S.U., Shirazi, S.M., Adham, A.K.M. and Hye, M.A. (2002). Response of maize to irrigation and nitrogenous fertilizer. Bangladesh J. Agric.Sci. 29(2),283-289.

Pandey, B.R., Adhikari, K. and Sharma, D. (2007). Evaluation of promising composite, synthetic and hybrid varieties of maize for grain yield and yield attributing traits. pp. 92-95. In:Gurung, D. B., Paudel, D.C., KC, G., Upadhaya, S.R. and B.B. Pokhrel. (eds.) Proceedings of the $25^{\text {th }}$ National Summer Crops Research Workshop on Maize Research and Production in Nepal held on June 21-23, 2007 at NARC, Khumaltar, Lalitpur, Nepal.

Paudyal, K.R., Ransom, J.K N., Rajbhandari, P., Adhikari, K.R., Gerpacio, V. and Pingali, P. L. (eds.) (2001). Maize in Nepal: Production Systems, constraints and priorities for research. NARC and CIMMYT. Kathmandu. Nepal, 48p.

Poneleit, C.G. and. Egli, D.B. (1979). Kernel growth rate and duration in maize as affected by plant density and genotype. Crop Sci. 19, 385-388.

Prassad, K. and Singh, P. (1990). Response of promising rainfed maize (Zea mays) varities to nitrogen application in north-western Himalayan region. Ind. J. Agric. Sci. 60(7), 475-477.

Rai, K.D. (1961). Response of maize following sorghum to fertilizers and foliar spray of zinc sulphate at Tozi, Sudan. Ind. J. Agron. 5(1), 176-187.

Ritchie, J.T. and Alagarswamy, G. (2003). Model concepts to express genetic differences in maize yield components. Agron. J. 95, 4-9.

Scarsbrook, C.E. and Doss, B. D. (1973). Leaf area index and radiation as related to corn yield. Agron. J. 65(3), 459-461.

Shrestha, J. (2007). Growth and productivity of winter maize under different levels of nitrogen and plant population. M.Sc. Ag. Thesis, Institute of Agriculture and Animal Science, Rampur. pp. 113.

Singh, D.P., Rana, N.S. and Singh, R.P. (2000). Growth and yield of winter maize (Zea mays L.) as influenced by intercrops and nitrogen application. Ind. J. Agron. 45, 515-519.

Thakur, D.R., Prakash, O., Kharwara, P.C. and Bhalla, S.K. (1997). Effect of nitrogen and plant spacing on yield, nitrogen uptake and economics in baby corn (Zea mays L.). Ind. J. Agron. 43(4), 668-671. 
Thapa, R.B. and Dangol, D.R. (1988). A preliminary survey of weed flora at IAAS and its vicinity. pp. 59-65. In: F. P. Neupane (ed.) IAAS Research Report (1985-1991). Institute of Agriculture and Animal Science, Rampur, Chitwan, Nepal.

Tollenaar, A., Aguilera, A. and Nissanka, S P. (1997). Grain yield is reduced more by weed interference in an old than in a new maize hybrid. Agron. J. 89, 239-246.

Ullah, A.M., Bhatti, A., Gurmani, Z.A. and Imran, M. (2007). Studies on planting patterns of maize facilitating legumes intercropping. J. Agric. Res. 45(2), 1-5.

Vega, C.R.C., Sadras, V.O., Andrade, F.H. and Uhart, S.A. (2000). Reproductive allometry in soybean, maize and sunflower. Ann. Bot. 85,461-468. 